\title{
A moral question for patent legislation
}

Richard Price and Simon Cohen

\section{In considering the grounds on which to award patents for applications of germline gene therapy, the European Patent Office may have to decide on the basis of "morality". This should not be its job.}

THE European Patent Office (EPO) is facing a delicate decision: whether to allow an application to patent germline gene therapy. A research group at the University of Pennsylvania (see Nature 368,$572 ; 1994$ ) has outlined a technique of altering the germ line of animals by among other things, arranging that the testes should produce only genetically engineered spermatozoa, so that the offspring inherit only the specified genes. The detailed scope of the patent application will become known only when it is published. But the principle is clear. Unlike somatic gene therapy, in which the alterations affect only the patient (in cystic fibrosis sufferers, for example, only the cells lining the patient's lungs), germline gene therapy affects the patient's offspring. This raises concern about the possible abuse of such treatment.

The European Patent Convention is an agreement signed by all EC states. Austria, Sweden and Switzerland. National patent laws in all these countries have been amended to conform with it. Under its provisions, before granting a patent, the EPO has to consider requirements of novelty, inventive step, sufficiency of disclosure, industrial application and, most controversially, morality.

Novelty. An invention must be new in the sense that it must not form "part of the state of the art". The test is one of worldwide novelty, so that a prior disclosure anywhere will prevent the grant of a patent. Under US law, however, applicants have one year after disclosure in which to file a patent application. In contrast to somatic gene therapy (more than 50 trials of which are planned or under way), germline gene therapy is likely to be a novel process according to this definition.

Inventive step. An invention has an inventive step if "having regard to the state of the art, it is not obvious to a person skilled in the art". The EPO must be satisfied that, given the state of the art at the time of the application, the invention does not involve the exercise of any ability beyond that to be expected of the ordinary person "skilled in the art".

Disclosure of the invention (sufficiency). The application must also disclose the invention in a manner sufficiently clear

This is the first of an occasional series of articles on intellectual property rights and the law. and complete for it to be carried out by a person skilled in the art. This is to ensure that the application contains sufficient technical information to enable that person to put the invention into practice, and to enable the reader to understand the contribution that the inventor has made. Industrial application. An invention must also be capable of industrial application: capable of being "made or used in any kind of industry, including agriculture". However, methods for treatment by surgery or therapy are not considered to be capable of industrial application. Therapy implies the curing of a disease or malfunction of the body and covers prophylactic treatment, for example immunization. Treatments which are not curative are therefore patentable. A borderline case was the patent for killing body lice in situ, which was allowed by the English High Court on appeal from the UK Patent Office. This exception covering methods for treatment will be of little help to the EPO in deciding on patentability for germline gene therapy. Whereas a patent for somatic gene therapy itself may come within the exception (for example the cystic fibrosis therapy referred to above), germline gene therapy, not necessarily having a curative effect and affecting later generations, would probably not. So the EPO will have to consider the morality question.

Morality. The European Patent Convention precludes the patenting of inventions. the publication or exploitation of which would be "contrary to ordre public or morality". The EPO guidelines state that this provision is to exclude inventions likely "to induce riot or public disorder, or to lead to criminal or other generally offensive behaviour". The example given. unhelpfully, is a letter-bomb!

On the limited information available at the moment, we understand that the "germline" patent is very broad in its range of applications. It relates to animals, human beings included. It aims to cover the curing of a particular gene defect as well as the removal of sperm (where there may be no particular gene defect) and replacement with "superior" sperm. Some of these applications will inevitably seem more "immoral" than others.

According to the doctrine of the separation of powers, a moral decision is not a decision that patent offices should be called on to make. It should be reserved for the political power. When the decision has been made, it should be formulated in primary legislation, with the rules and guidance needed for its application in individual cases clearly set out. While application of the law may involve a moral judgment in a marginal case, patent offices should not have to make a moral choice. They apply a series of essentially technical tests to decide whether a patent should be granted. Requiring them to decide this moral question is beyond their competence and may result in them failing to give a proper moral judgment, and in muddling the technical assessment.

The EPO had to consider the issue in the application for the Oncomouse, a mouse developed at Harvard University whose offspring develop tumours soon after birth. Balancing the suffering of animals and possible risks to the environment against the invention's usefulness, the EPO decided that the "Oncomouse"s purpose of facilitating cancer research and treatment was of paramount importance for the welfare of mankind" and granted the application. But the patent is now being opposed.

More guidance is clearly required for patent offices and inventors. One possible way forward is to set up an ethics committee. If a patent raises morality concerns when it is examined then it could be granted subject to conditions as to its exploitation. The patent owner would then have to clear its mode of exploitation with the ethics committee in advance. There are two main reasons why this suggestion makes sense: first, because the vast majority of granted patents are never commercialized - why should the EPO spend considerable time dealing with such issues when the patent may never be exploited? Second, in many instances (as in the germline application) the patent is broad. By involving the ethics committee at a later date, when commercialization is in sight, the EPO would be able to see how an invention would practically be exploited before making its final decision.

Whether or not this particular idea finds favour, some changes will surely have to be made. Otherwise, the EPO is bound to face many more biotechnology applications giving rise to unnecessary controversy, and causing the public to ask whether patent law is coping with the pace of technological change.

The authors are solicitors at Taylor Joynson Garrett, London EC4Y ODX, UK. 